\title{
Editorial
}

\section{Obstetrics and Gynecology in Indonesia and Its Challenges in the Near Future}

\section{Noroyono Wibowo}

Indonesia's vast and various characteristics of its social, economic, and geographic conditions affect variations in service needs in the field of Obstetrics and Gynecology, which bring about several great challenges to face.

There has not been standardized electronic medical record system utilized by all obgyn practitioners in Indonesia. This leads to difficulty in access to real-time actual data about issues around OBGYN. In the absence of real-time accurate data, the issues put on the table is merely an assumption or an estimation. Thus, prioritization of problem solving is almost impossible, neither distribution of task force which serve as think tank centre for specific issues. As surveillance towards each disease is practically non-existent, disease management is performed impromptu rather than organized.

Being shackled by global mindset and concurrently forgetting local wisdom. One should not forget that variations in response to therapy and disease patterns are influenced by local behaviour, nutrigenomic, epigenetic, and environment. The preference of curative management instead of prevention, leading to insignificant decline in mortality and morbidity.

Big data will soon be a prerequisite in managing diseases, therefore understanding the use and the interpretation of artificial intelligence is imperative. In obstetrics, cases of Great Obstetrics Syndrome (GOS), consisting of preeclampsia, preterm labor, intrauterine growth restriction (IUGR), and gestational diabetes will remain dominant in services, followed by autoimmune and cardiac abnormalities. In gynecology, Polycystic Ovaries (PCO), endometriosis, myoma, and menstrual disorders will remain major issues, followed by the alternation between ovarian and endometrial malignancy.

Perkumpulan Obstetri Ginekologi Indonesia (POGI) has to stress the fact that humans, through their reproductive nature, are the main assets of the country, hence they have to be the main subject in drafting the state budget. Indeed, a nation with poor reproductive function, quality, and results will soon or later vanish, if not colonized. 


\section{REFERENCES}

1. Marica Franzago, Federica Fraticelli, Liborio Stuppia \& Ester Vitacolonna. Nutrigenetics, epigenetics and gestational diabetes: consequences in mother and child, Epigenetics. 2019;14(3): 215-35, doi: 10.1080/15592294.2019.1582277.

2. Prasoon Agarwal, Taylor S. Morriseau, Stephanie M. Kereliuk, Christine A. Doucette, Brandy A. Wicklow \& Vernon W. Dolinsky. Maternal obesity, diabetes during pregnancy and epigenetic mechanisms that influence the developmental origins of cardiometabolic disease in the offspring, Critical Reviews in Clinical Laboratory Sciences. 2018; 55(2): 71101. doi: 10.1080/10408363.2017.1422109.

3. Okezie I Aruoma, Sharon Hausman-Cohen, Jessica Pizano, Michael A. Schmidt, Deanna M. Minich, Yael Joffe, Sebastian Brandhorst, et al,. Personalized Nutrition: Translating the Science of Nutri Genomics into Practice: Proceedings from the 2018 American College of Nutrition Meeting, J Am Coll Nutr. 2019; 38(4):, 287-301. doi: 10.1080/07315724.2019.1582980.

4. Corinne L. Bush, Jeffrey B. Blumberg, Ahmed El-Sohemy, Deanna M. Minich, Jóse M. Ordovás, Dana G. Reed \& Victoria A, et al,. Toward the Definition of Personalized Nutrition: A Proposal by The American Nutrition Association. J Am Coll Nutr. 2020; 39(1): 5-15. doi: 10.1080/07315724.2019.1685332.

5. Roger S. Newton, Jeffrey B. Blumberg, Dana G. Reed \& Michael A. Stroka. The American Nutrition Association ${ }^{\circledR}$ : Championing the Science and Practice of Personalized Nutrition. J Am Col Nutr. 2020; 39(1): 1-4. doi: 10.1080/07315724.2020.1699380.

6. Taylor C. Wallace, Scott Bultman, Chris D'Adamo, Carrie R. Daniel, Justine Debelius, Emily Ho, Heather Eliassen, et al,. Personalized Nutrition in Disrupting Cancer — Proceedings From the 2017 American College of Nutrition Annual Meeting. J Am Coll Nutr. 2019; 38(1): 1-14. doi: 10.1080/07315724.2018.1500499

7. Nafee T, Farrell W, Carroll W, Fryer A, Ismail K. Epigenetic control of fetal gene expression. BJOG. 2008;115:158-68.

8. Krakowsky RHE and Tollefsbol TO. Impact of nutrition on non-coding RNA epigenetics in breast and gynecological cancer. Front. Nutr. 2015; 2:16. doi: 10.3389/fnut.2015.00016.

9. Mandakh Y, Rittner R, Flanagan E, Oudin A, Isaxon C, Familari M, et al,. Maternal Exposure to Ambient Air Pollution and Risk of Preeclampsia: A Population-Based Cohort Study in Scania, Sweden. Int J Environ Res Public Health. 2020;17(5):1744. doi: 10.3390/ijerph17051744. PMID: 32155988; PMCID: PMC7084298.

10. Christians JK, Leavey K, Cox BJ. Associations between imprinted gene expression in the placenta, human fetal growth and preeclampsia. Biol. Lett. 2017:13. 20170643. http://dx.doi.org/10.1098/rsbl.2017.0643.

11. Iftikhar P, Kuijpers M V, Khayyat A, et al. Artificial Intelligence: A New Paradigm in Obstetrics and Gynecology Research and Clinical Practice. Cureus. 2020; 12(2): e7124. doi 10.7759/cureus.7124

12. Emin EI, Emin E, Papalois A, Willmott F, Clarks S and Sideris M. Artificial Intelligence in Obstetrics and Gynaecology: Is This the Way Forward? in vivo. 2019;33:1547-51. doi:10.21873/invivo.11635.

13. van Uitert EM, van Ginkel S, Willemsen SP, Lindemans J, Koning AHJ, Eilers PHC et al,.. An optimal periconception maternal folate status for embryonic size: the Rotterdam Predict study. BJOG. 2014;121:821-9.

14. Alegría-Torres JA, Baccarelli A, Bollati V. Epigenetics and lifestyle. Epigenomics. 2011;3(3):267-77. doi: 10.2217/ epi.11.22. PMID: 22122337; PMCID: PMC3752894.

15. Benachi $A$., Relationship between vitamin $D$ status in pregnancy and the risk for preeclampsia: a nested case control study, Clin Nutr, https://doi.org/10.1016/j.clnu.2019.02.015

16. Izetbegovic S, Alajbegovic J, Mutevelic A, Pasagic A, Masic I. Prevention of diseases in gynecology. Int J Prev Med. 2013;4(12):1347-58. PMID: 24498489; PMCID: PMC3898439.

17. N. Halfon. (eds.), Handbook of Life Course Health Development, DOI 10.1007/978-3-319-47143-3_18

18. Banik A, Kandilya D, Ramya S, Stünkel W, Chong YS, Dheen ST. Maternal Factors that Induce Epigenetic Changes Contribute to Neurological Disorders in Offspring. Genes (Basel). 2017; 24;8(6):150. doi: 10.3390/genes8060150. PMID: 28538662; PMCID: PMC5485514. 